\title{
Analysis the Effect of Service Quality, Price and Facilities on Customer Loyalty in Central Motor Garage (Case Study of Pandaan Central Motor Garage)
}

\author{
Ennis Mu'faridah \\ Narotama University Indonesia \\ ennismufaridah22@gmail.com
}

\begin{abstract}
This study aims to analyze the effect of service quality, price and facilities on customer loyalty at the Central Motor Garage in Pandaan. The research used purposive sampling, and the sample taken were 100 respondents. Analysis technique used was multiple linear regression. The results of the analysis simultaneously show that service quality, price and facilities are significant to customer loyalty and partially show service quality, price and facilities have a significant effect on customer loyalty. The results of the analysis of the coefficient of determination are known to be $74.6 \%$ variable customer loyalty can be requested by variables of service quality, price and facilities, while $25.4 \%$ are read by other variables not available in this study.
\end{abstract}

Keywords: Service quality, Price, Facilities, Customer loyalty

\section{INTRODUCTION}

In the era of business competition that was so tight as now the number of products and brands, both trade and services that compete very much. Marketing has a very important role for goods and services companies. This intense competition requires business people to be able to maximize company performance and create appropriate strategies to be able to compete in the market.

Given the tight business competition in the field of automotive services, especially in motorcycle products, consumers have a variety of choices and this is an alternative challenge for the company so that Companies must be able tohave a way ts to increase the proportion of value.

One automotive service company that competes is Central Motor Garage. Central Motor Garage is a form of business engaged in motorcycle service and sales of motorcycle parts. Providing the best service is a commitment from the Central Motor garage. This is the way the company maintains its customers. .

Customer loyalty has an important role in a company and having loyal customers is the ultimate goal of all companies. maintaining them means improving financial performance and maintaining the survival of the company, this is the main reason for a company to attract and retain consumers. Efforts to obtain loyal customers cannot be done just like that, but through several stages, ranging from finding potential customers to acquiring partners. Therefore to maintain the business life cycle of the company must be able to maintain excellence and pay attention to the quality of products and services by using attractive marketing strategies and prices that are appropriate in the eyes of consumers, in addition to service companies is very important to pay attention to the quality of services and facilities provided to consumers.

The objectives of this study are:

1. To analyze the effect of simultaneously variable service quality, price and facilities on customer loyalty at the Central Motor garage in Pandaan.

2. To analyze the influence of partial service quality variables, prices and facilities on customer loyalty at the Central Motor garage in Pandaan. 


\section{LITERATURE REVIEW}

\subsection{Service quality}

Service quality is the totality of the characteristics of goods and services that show their ability to satisfy customer needs, both those that appear clear and hidden. For companies engaged in the service sector, providing quality services to customers is an absolute thing to do if the company wants to achieve success. [5]

Measurement of service quality is based on a multi-item scale designed to measure customer expectations and perceptions. Thus, there are five main dimensions, including [11] :

1. Reliability, namely the ability to provide promised services promptly, accurately and satisfactorily.

2. Responsiveness, namely the desire of staff to help customers and provide service responsibly.

3. Assurance, including knowledge, competence, politeness, and the trustworthiness of staff, free from danger, risk or doubt.

4. Empathy (Emphaty), including ease in establishing relationships, good communication, personal attention, and understanding of the individual needs of customers.

5. Tangible, includes physical facilities, equipment, employees, and means of communication.

\subsection{Price}

Prices have an important role in the marketing mix, because prices determine how much profit or company revenue is generated from the sale of products and services. Price is one of the important variables in marketing, where prices can influence consumers in making decisions to buy a product, for various reasons. [1]Price is the amount of money set by the product to be paid by consumers or customers to cover the costs of producing, distributing and selling the principal, including returns that mark the business and the risks. [6]

\subsection{Facilities}

Facilities is physical resources that must exist before a service is offered by consumers. [1] Facilities are all things that can facilitate and facilitate the implementation of a business. [12] Facilities can also be interpreted as facilities and infrastructure that are available in the environment and inside the company's office, intended to provide maximum service so that consumers or customers feel comfortable and satisfied. Facilities are the main supporting factors in the activities of a product. [7]

\subsection{Customer loyalty}

Loyal customers are "A loyal customer is one who makes regular repeat purchases across product and service lines, referring others and demonstrating immunity to the pull of the competition". [4]

\subsection{Conceptual Framework}

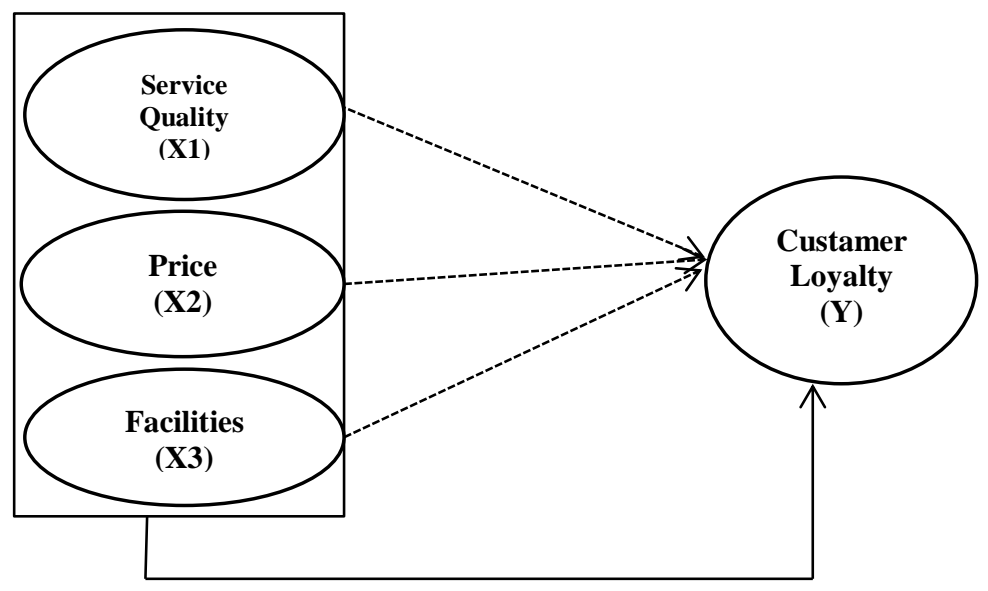

Fig. 1 Conseptual Framework

\subsection{Hypothesis}

H1: There is a significant simultaneous influence between service quality variables (X1), Price (X2), facilities (X3) on customer loyalty (Y) in Central Motor's garage in Pandaan. 
H2: There is a partially significant influence between Service Quality variable (X1), Price (X2), facilities (X3) on Customer Loyalty (Y) in Central Motor garage in Pandaan.

\section{RESEARCH METHODOLOGY}

\subsection{Research Approach}

In preparing this study, the authors used a research approach with quantitative research methods, namely research to prove theory / truth, build facts, show relationships between variables, provide statistical descriptions, estimate and predict results with systematic research procedures, data in numerical or numerical terms and analyzed with statistical procedures

\subsection{Population and sample}

The population is a region of generalization consisting of objects / subjects that have certain qualities and characteristics set by researchers to be studied and then conclusions drawn [8]. The population in this study were all customers from the Central Motor Pandaan garage.

Determination of taking a sample whose population is large and the number is unknown using a formula [9]:

Where :

$$
n=\frac{\mathrm{Z}^{2}}{4(M o e)^{2}}
$$

$\mathrm{n}=$ Number of samples

$\mathrm{z}=$ The level of confidence needed in determining the number of samples is $95 \%=1,96$

Moe = margin of error or maximum error that can be tolerated by $10 \%$.

From the formula, the calculation of the sample is as follows:

$$
\begin{gathered}
=\frac{1,96^{2}}{4(M o e)^{2}} \\
n=\frac{1.96^{2}}{4(0,1)^{2}} \\
n=96,04
\end{gathered}
$$

From the results of the calculation above, the number of samples that must be studied is 96 , 4 respondents. But to facilitate research, the researcher took a sample of 100 respondents. The sampling technique in this study used purposive sampling.

\subsection{Data Type}

The types of data used in this study are:

1. Quantitative Data : that is the type of data that can be measured or calculated directly and expressed in the form of numbers or numbers.

2. Qualitative Data : i.e. the type of data from explanation in the form of descriptions in the form of sentences and cannot be analyzed in the form of numbers or numbers.

\subsection{Data source}

1. Primary Data is data obtained directly from the source of the research.

2. Secondary data is data obtained from sources other than informants

\subsection{Data collection technique}

1. Library research : collect data and theories that are relevant to the problems in this study by conducting library research on literature and other library materials

2. Interview: do question and answer directly with the person concerned.

3. Questionnaire: spread questionnaires containing lists of questions to respondents.

4. Observation: observe activities directly at the scene of events related to research problems to obtain a conclusion in the retrieval of the data.

\subsection{Analysis Method}

Analyisis data in this study using multiple linear regression, including correlation coefficient, coefficient of multiple determination, then test $\mathrm{T}$ and $\mathrm{F}$ test. 


\subsection{Reliability Test}

Reliability test is a tool used to measure the consistency of a questionnaire which is an indicator of a variable or construct [2]. The basis of decision making for measuring reliability tests to be used in this study is to use SPSS (Statistical Package for Social Science) analysis version 16, namely with Cronbach Alpha statistical tests. A construct or variable is declared reliable if the cronbach alpha value is $>0.60$ [2].

\subsection{Validity test}

Validity test is used to measure valid or not the questionnaire. Decision making to measure validity can be done by making a correlation between the scores of questions with a total score construct or variable. That is by comparing the value of $r$ count with $r$ table for the degree of freedom $(d f)=n-2$, where (n) is the number of research samples. If $r$ count $>r$ table and positive value then the item or question or indicator is declared valid [3].

\subsection{Normal Distribution Test}

In this study the normal distribution test uses Kolmogorov Smirnov analysis using the SPSS for Windows version 23.0 program. The basic concept of Kolmogorov Smirnov's analysis is to compare the distribution of data (which will be tested for normality) with the standard normal distribution.

\subsection{Multiple Linear Regression Test}

Multiple linear regression analysis is used to determine the extent of the influence of the independent variable $(\mathrm{X})$ on the dependent variable $(\mathrm{Y})$. The multiple linear regression equation model is as follows:

Where:

Y : Customer loyalty

b1, b2, b3 : Coefficient regression

$\mathrm{X} 1 \quad$ : Product quality

$\mathrm{X} 2 \quad$ : Service quality

$\mathrm{X} 3 \quad$ : CUstomer trust

E $\quad$ : error

\subsection{Hypothesis testing}

\section{Simultaneous Test (F)}

The $\mathrm{F}$ test is used to determine the level of significance of the effect of independent variables simultaneously on the dependent variable [3]. The hypothesis used in this study are:

Ho: Independent variables consisting of service quality (X1), price (X2), facilities (X3) simultaneously have no significant effect on the dependent variable, namely customer loyalty ( $\mathrm{Y})$.

Ha: Independent variables consisting of service quality (X1), price (X2), facilities (X3) simultaneously have a significant effect on the dependent variable, namely customer loyalty (Y).

The basis for decision making in this test is to use probability probability numbers, namely [3]:

a. if the probability of significance is $>0.05$, then Ho is accepted and Ha is rejected.

b. if the probability of significance is $<0.05$, then Ho is rejected and Ha.

\section{Partial Test (P)}

The $t$ test is used to test the significance of the relationship between variables $\mathrm{X}$ and $\mathrm{Y}$, whether the variable Quality of Service Price, Facility, really affects the variable customer loyalty separately or partially [3]. The hypothesis used in this test is:

Ho: Independent variables consisting of service quality (X1), price (X2), facilities (X3) partially have no significant effect on the dependent variable, namely customer loyalty $(\mathrm{Y})$.

Ha: Independent variables consisting of service quality (X1), price (X2), facilities (X3) partially have a significant effect on the dependent variable, namely customer loyalty $(\mathrm{Y})$.

The basis of decision making [3]. is to use probability probability numbers, namely:

a. If the probability number is significant $>0.05$, then Ho is accepted and $\mathrm{Ha}$ is rejected.

b. If the probability of significance is $<0.05$, then Ho is rejected and $\mathrm{Ha}$ is accepted. 


\subsection{Classic assumption test}

1. Multicollinearity test

The multicollinearity test aims to test whether the regression model is found to have a correlation between independent variables. to detect the presence or absence of multicollinearity in the regression model can be seen from the tolerance value and Variance Inflation Factor (VIF), the common cutoff value to indicate the multicollinearity problem is Tolerance $<0.10$ or equal to the value of VIF $>10$. [2].

\section{Heterocedasticity test}

The heteroscedasticity test aims to test whether in the regression model there are similarities in the variance from the residuals, one observation to another observation. The basic analysis of heterocedasticity test is [3]:

a. If there are certain patterns, such as the existing points form a certain pattern Regular (wavy, widened and then narrowed), then indicates heteroscedasticity has occurred.

b. If there are no clear patterns, as well as points above and below the number 0 on the $\mathrm{Y}$ axis, there is no heteroscedasticity.

\section{Normality Test}

The normality test aims to test whether the regression model of the confounding or residual variables has a normal distribution. the basis for decision making in the normality test is as follows [2]:

a. If the data (point) spreads around the diagonal line and follows the direction of the line diagonal or graph shows the pattern of normal distribution, then the regression model meets the assumption of normality.

b. If the data (point) spreads far from the diagonal and or does not follow the direction of the diagonal line or the graph does not show a normal distribution pattern, then the regression model does not meet the normality assumption.

\section{RESEARCH RESULTS AND DISCUSSION}

\subsection{Reliability Test}

Table 1. Reliability Test Results

Reliability Statistics

\begin{tabular}{|c|c|}
\hline Cronbach's Alpha & N of Items \\
\hline 0.939 & 14 \\
\hline
\end{tabular}

Source: SPSS.23 Analysis Results. 2019

Based on table 1, the cronchbach alpha value of all indicators is 0.939 and is greater than 0.60 , meaning that the measuring instrument or questionnaire instrument used in this study is reliable.

\subsection{Test Validity}

Table 2. Validity Test Results Item-Total Statistics

\begin{tabular}{|c|c|c|l|l|}
\hline & $\begin{array}{l}\text { Scale Mean if } \\
\text { item Deleted }\end{array}$ & $\begin{array}{l}\text { Scale Variance } \\
\text { if the item is } \\
\text { Deleted }\end{array}$ & $\begin{array}{l}\text { Corrected Item- } \\
\text { Total } \\
\text { Correlation }\end{array}$ & $\begin{array}{l}\text { Cronbach's } \\
\text { Alpha if item } \\
\text { Deleted }\end{array}$ \\
\hline X1.1 & 40.98327 & 65,648 & .654 & .935 \\
X1.2 & 40.80602 & 67,494 & .527 & .939 \\
X1.3 & 40.79913 & 68,498 & .469 & .940 \\
X1.4 & 40.86976 & 65,308 & .682 & .935 \\
X1.5 & 41.01683 & 65,730 & .658 & .935 \\
X2.1 & 40.77805 & 65,007 & .706 & .934 \\
X2.2 & 41.01570 & 64.127 & .767 & .932 \\
X2.3 & 41.02814 & 65,015 & .776 & .932
\end{tabular}




\begin{tabular}{|c|l|l|l|l|}
$\mathrm{X} 3.1$ & 40.95847 & 65,444 & .752 & .933 \\
$\mathrm{X} 3.2$ & 41.02853 & 64.251 & .754 & .932 \\
$\mathrm{X} 3.3$ & 40.71743 & 63,068 & .826 & .930 \\
$\mathrm{Y} .1$ & 40.72547 & 62,932 & .822 & .930 \\
$\mathrm{Y} .2$ & 41.03898 & 64,342 & .734 & .933 \\
$\mathrm{Y} .3$ & 40.76497 & 67,308 & .657 & .935 \\
\hline
\end{tabular}

Source: SPSS.23 Analysis Results. 2019

Based on Table 4 shows that all indicators have a calculated $r$ (Corrected ItemTotal Correlation ) greater than $r$ table $=0.1966$ so that empirically can be proven that all indicators in this questionnaire are valid.

\subsection{Normal Distribution Test}

Table 3. Result of Normal Distribution Test One-Sample Kolmogorov-Smirnov Test

\begin{tabular}{|c|c|c|c|c|c|}
\hline & & $\mathrm{X} 1$ & $\mathrm{X} 2$ & X3 & $\mathrm{Y}$ \\
\hline $\mathrm{N}$ & & 100 & 100 & 100 & 100 \\
\hline \multirow[t]{2}{*}{ Normal Parameters ${ }^{\mathrm{a}, \mathrm{b}}$} & Mean & 3.9780 & 3.6680 & 3.7330 & 3.8658 \\
\hline & Std. Deviation & .77410 & .71050 & .72425 & .70925 \\
\hline \multirow[t]{3}{*}{ Most Extreme Differences } & Absolute & .088 & .080 & .085 & .079 \\
\hline & Positive & .060 & .080 & .085 & .072 \\
\hline & Negative & -.088 & -.066 & -.072 & -.079 \\
\hline Test Statistic & & .088 & .080 & .085 & .079 \\
\hline Asymp. Sig. (2-tailed) & & $.055^{\mathrm{c}}$ & $.112^{\mathrm{c}}$ & $.069^{c}$ & $.125^{\mathrm{c}}$ \\
\hline
\end{tabular}

Source: SPSS.23 Analysis Results. 2019

In this study the normal distribution test uses Kolmogorov Smirnov analysis using the SPSS for Windows version 23.0 program. The basic concept of Kolmogorov Smirnov's analysis is to compare the distribution of data (which will be tested for normality) with the standard normal distribution.

\subsection{Multiple Linear Regression Analysis}

Table 4. Results of Multiple Linear Regression Analysis Coefficients ${ }^{\text {a }}$

\begin{tabular}{|c|c|c|c|c|c|}
\hline \multirow[t]{2}{*}{ Model } & \multicolumn{2}{|c|}{$\begin{array}{c}\text { Unstandardized } \\
\text { Coefficients }\end{array}$} & $\begin{array}{l}\text { Standardized } \\
\text { Coefficients }\end{array}$ & \multirow[t]{2}{*}{$\mathrm{t}$} & \multirow[t]{2}{*}{ Sig. } \\
\hline & $\mathrm{B}$ & Std. Error & Beta & & \\
\hline (Constant) & -.298 & .209 & & -1.428 & .157 \\
\hline $\mathrm{X} 1$ & .314 & .063 & .290 & 4,993 & .000 \\
\hline $\mathrm{X} 2$ & .303 & .112 & .301 & 1956 & .004 \\
\hline $\mathrm{X} 3$ & .452 & .113 & .412 & 4,001 & .000 \\
\hline
\end{tabular}

Source: Primary data if the author. 2019

Regression equation model :

$$
\mathrm{Y}=\mathrm{Y}=-0.298+0.314 \mathrm{X}_{1}+0.330 \mathrm{X}_{2}+0.452 \mathrm{X}_{3}+0.787
$$

The interpretation of the regression model equation above can be explained as follows:

1. A constant value of $=-0.298$ meaning that if the service quality, price and facilities do not have a value $\left(\mathrm{X}_{1}, \mathrm{X}_{2} \mathrm{X}_{3}=0\right)$, customer loyalty $\mathrm{Y}$ is worth $=-0.298$.

2. Regression coefficient value on service quality variable $=0.314$, indicating that every change or increase in service quality unit is equal to one unit, thus increasing customer loyalty by $31.4 \%$.

3. The regression coefficient value of the variable price $=0.330$, shows that each change in the unit price of one unit will increase customer loyalty by $33 \%$.

4. Regression coefficient value at facility variable $=0.452$, indicating that after each change or increase in unit facilities by one unit, it will increase customer loyalty by $45,2 \%$. 
5. Standard Error Estimate (SEE) on service quality variables (X1), price (X2) and facilities $(\mathrm{X} 3)=$ 0.787, shows that the numbers are relatively small so that the multiple linear regression model in this study is more accurate in presenting customer loyalty to the Central Motor workshop in Pandaan.

\subsection{Simultaneous Test (F)}

Table 5. Simultaneous Test Results (F)

ANOVA ${ }^{\text {a }}$

\begin{tabular}{|ll|l|l|l|l|l|}
\hline Model & Sum of Squares & df & Mean Square & F & Sig. \\
\hline 1 & Regression & 46,131 & 3 & 15,377 & 97,940 & $.000^{\mathrm{b}}$ \\
& Residual & 15,072 & 96 & .157 & & \\
Total & 61,204 & 99 & & & \\
\hline
\end{tabular}

Source: Primary data is processed by the author. 2019

In Table 4, the results of the F test indicate that the variables of Service Quality, Product Quality, and Price simultaneously influence Customer Loyalty which can be seen from F Count 97,940 which means F count $>\mathrm{F}$ table (df 96, 0.05) 2.70 and significance probability level $0.00<0.05$

\subsection{Partial Test (T)}

Table 6. Partial Test Results (T)

Coefficients $^{\text {a }}$

\begin{tabular}{|c|c|c|c|c|c|}
\hline \multirow[t]{2}{*}{ Model } & \multicolumn{2}{|c|}{ Unstandardized Coefficients } & $\begin{array}{l}\text { Standardized } \\
\text { Coefficients }\end{array}$ & \multirow[t]{2}{*}{$\mathrm{T}$} & \multirow[t]{2}{*}{ Sig. } \\
\hline & $\mathrm{B}$ & Std. Error & Beta & & \\
\hline 1 (Constant) & -.298 & .209 & & -1.428 & .157 \\
\hline $\mathrm{X} 1$ & .314 & .063 & .290 & 4,993 & .000 \\
\hline $\mathrm{X} 2$ & .303 & .112 & .301 & 1956 & .004 \\
\hline $\mathrm{X} 3$ & .452 & .113 & .412 & 4,001 & .000 \\
\hline
\end{tabular}

Source: Primary data is processed by the author. 2019

Based on the table above can be explained as follows:

1. Service quality variable $(\mathrm{X} 1)$ obtained $\mathrm{T}$ count $=4,993>\mathrm{T}$ table $=1,984$ with a probability level of $0,000<0.05$. means that $\mathrm{Ha}$ is accepted and Ho is rejected, then partially the service quality variable (X1) has a significant effect on customer loyalty variable (Y)

2. Price variable $(\mathrm{X} 2)$ obtained $\mathrm{T}$ count $=2.956>\mathrm{T}$ table $=1.984$ with a probability level of 0.004 $<0.05$. means that $\mathrm{Ha}$ is accepted and Ho is rejected, then partially the price variable (X2) has a significant effect on customer loyalty variable (Y)

3. Facility variable $(\mathrm{X} 3)$ obtained a $\mathrm{T}$ value $=4.001>\mathrm{T}$ table $=1984$ with a probability level of 0.000 $<0.05$. means that $\mathrm{Ha}$ is accepted and Ho is rejected, then partially the facility variable (X3) has a significant effect on customer loyalty variable $(\mathrm{Y})$.

\subsection{Coefficient of Determination}

The coefficient of determination $\left(\mathrm{R}^{2)}\right.$ aims to measure how far the model's ability to explain the variation of the dependent variable is customer loyalty (Y).

Table 7. Results of the Determination Coefficient

Model Summary ${ }^{b}$

\begin{tabular}{|c|c|c|c|c|}
\hline Model & $\mathrm{R}$ & $\mathrm{R}$ Square & Adjusted R Square & Std. Error of the Estimate \\
\hline 1 & $.868^{\mathrm{a}}$ & .754 & .746 & .39624 \\
\hline
\end{tabular}

a. Predictors: (Constant), X3, X1, X2

b. Dependent Variable: Y

Source: Primary data, processed by the author. 2019 
In the above table obtained by the coefficient of determination $\left(\mathrm{R}^{2)}\right.$ of 0.746 . This means that $74.6 \%$ Pelang loyalty variables influenced ol gan er variable quality of service, price and facilities so that $25.4 \%$ influenced by other variables outside the model of this study.

\subsection{Classic assumption test}

\section{A. Muktikolonieritas Test}

Table 8. Results of the Determination Coefficient Coefficients ${ }^{\text {a }}$

\begin{tabular}{|ll|l|l|}
\hline \multirow{2}{*}{ Model } & & \multicolumn{2}{l|}{ Collinearity Statistics } \\
\cline { 3 - 4 } & & Tolerance & VIF \\
\hline 1 & X1 & .762 & 1.312 \\
& X2 & .248 & 4,030 \\
& X3 & .241 & 4,144 \\
\hline
\end{tabular}

a. Dependent Variable: Y

Source: Primary data, processed by the author. 2019

Based on the table above, the results of the tolerance value of each independent variable are greater than 0.1 and the VIF value of each independent variable is less than 10. So it can be concluded that there is no multicollinearity between the independent variables in the regression model.

\section{B. Heterocedasticity Test}

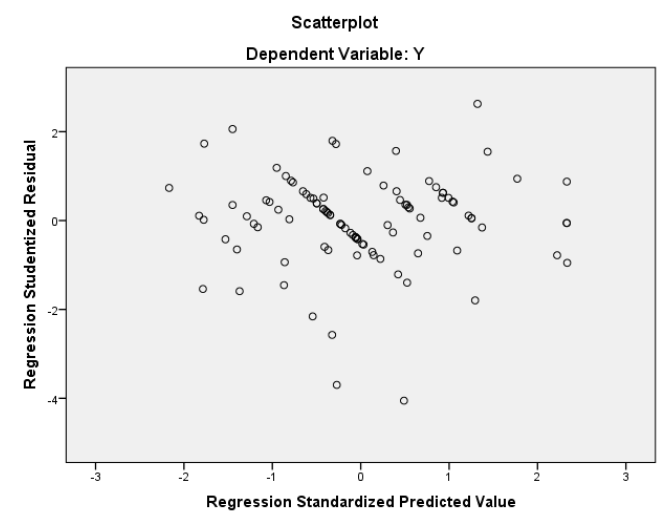

Fig. 2 Heterocedasticity Test Results

Source: Primary data is processed by the author.2019

Based on the graph above it is known that dots or plots do not form a specific pattern and the points or plots spread above and below the number 0 of the $\mathrm{Y}$ axis. Thus it can be concluded that the regression model used in this study did not occur heterocedasticity.

\section{Normality Test}

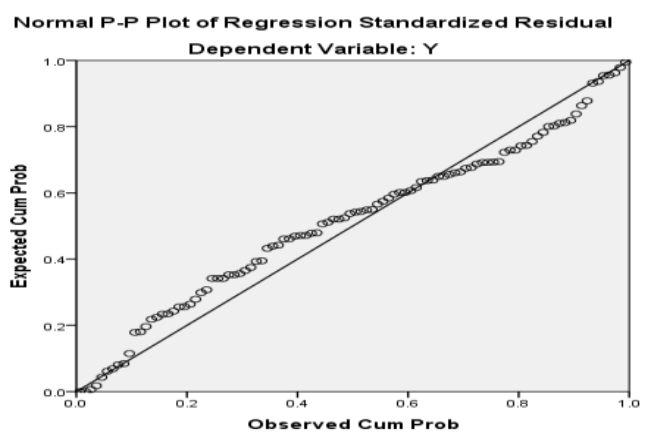


Fig. 3 Normality Test Results

Source: Primary data is processed by the author.2019

Based on the graph in the picture above shows points or plots spread around the diagonal line and follows the direction of the diagonal line. Thus it can be assumed that the regression model in this study is normally distributed.

\section{CONCLUSIONS}

The conclusions from the results of this study are :

1. Based on a simultaneous test $(F)$ that all research variables consisting of service quality, price and facilities have a significant effect simultaneously on variable customer loyalty. This is evidenced by the results of the F count $>\mathrm{F}$ table which is $97,490>2.70$ with a probability level $<0.05$ which is 0.00 $<0.50$. Thus the first hypothesis that the authors put forward in this study is empirically proven to be true and acceptable.

2. Based on the partial test $(\mathrm{T})$ that all variables in the study consisting of service quality, price and facilities have a significant effect partially on the variable customer loyalty. This is evidenced by the results of the calculated $\mathrm{T}$ value of each variable $>\mathrm{T}$ table, which is the variable quality of service $4,993>1,984$ with a significance probability level of $<0.05$, that is $0,000<0.05$, variable price of $2,956>1,984$ with a significance probability level $<0.05$ which is $0.004<0,05$ and facility variable $4,001>1,984$ with a probability level of significance $<0.05$ which is $0,000<0.05$. Thus the second hypothesis that the authors put forward in this study is empirically proven to be true and acceptable.

3. The results of the study also show that service quality variables are the dominant variables that influence customer loyalty compared to price and facilities variables.

4. From the results of multiple linear regression equations, it is known that the variables of service quality, price and facilities show a positive influence on customer loyalty at the Central Motor workshop in Pandaa

5. Of the coefficient of determination $\left(\mathrm{R}^{2}\right.$ ) obtained a value of 0.746 , meaning that $74.6 \%$ variable customer loyalty is influenced by the variable quality of service, price and facilities so that $25.4 \%$ influenced by other variables outside the model of this study.

\section{SUGGESTIONS}

Suggestions from this study are:

1. Central Motorbike Workshop Pandaan should maximize employee performance such as improving service quality in terms of reliability / responsiveness so that employees are faster and more responsive and able to fulfill customer desires according to customer desires, because if customers feel satisfied with the service provided by the customer will return to Central Motor Pandaan workshop.

2. Pricing at Central Motor workshops should be adjusted again to the quality of services and work results received by customers. Although the prices offered by central motorbike workshops are more affordable and cheaper than other competitor workshops.

3. The Central Motor Workshop should improve facilities such as providing a wider waiting room and paying attention to the cleanliness of the waiting room, especially toilets, so that customers feel more satisfied with the available facilities.

\section{REFERENCES}

[1] Augusty, Ferdinand : Metode penelitian Manajemen. Pedoman Penelitian untuk skripsi, Tesis dan Disertai Ilmu Manajemen Universitas Diponegoro, Semarang. (2008)

[2] Ghozali, Imam : Aplikasi Analisis Multivariate dengan program SPSS. Badan Penerbit Universitas Diponegoro, Semarang (2006) 
[3] Ghozali, Imam : Aplikasi Analisis Multivariate dengan Program SPSS. Badan Penerbit Universitas Diponegoro, Semarang. (2005)

[4] Griffin, Jill : Customer Loyalty. Menumbuhkan Dan Mempertahankan Kesetiaan Pelanggan. Airlangga, Jakarta. (2003)

[5] Kotler, Philip : Manajemen Pemasaran. Analisis, Perencanaan, Implementasi dan Pengendalian, Edisi 6, Jilid 2. Erlangga, Jakarta. (2000)

[6] Kotler, Philip : Marketing Management. Edisi Milenium, Prentice Hall Intl, Inc New Jersey. (2000)

[7] Sudono, Sukino : Teori Pengantar Mikro Ekonomi, Edisi 3. PT Raja Grafindo, Jakarta. (2005)

[8] Sugiyono : Metode Penelitian Pendidikan. Alfabeta, Bandung. (2010)

[9] Sugiyono : Statistika untuk penelitian. Alfabeta, Bandung (2012)

[10] Tjiptono, F : Manajemen Jasa 2nd ed. Andi offset, Yogyakarta. (2001)

[11] Tjiptono, Fandy : Pemasaran Jasa. C.V Andi Offset, Yogyakarta (2014)

[12] Wahyuningrum : Buku Ajar Manajemen Fasilitas Pendidikan Yogyakarta. FIP UNY, Yogyakarta. (2005) 